\title{
Certain economic instruments as a factor of realizing the potential of using alternative energy sources in Russia
}

\author{
Nadejda Ponomareva, Anna Zvereva, Ekaterina Golubtsova, Svetlana Ilyashenko* and Gennady Ivanov \\ Plekhanov Russian University of Economics, Stremyannyj lane, 36, Moscow, 115054, Russia
}

\begin{abstract}
With each passing year, the problem of using alternative energy sources is gaining increasing attention, since the energy of the sun, water and wind, unlike hydrocarbons, belongs to practically inexhaustible resources. Besides this, alternative energy sources are relatively environmentally friendly, so any country is interested in using them. One of the factors affecting the increase of energy generation from alternative sources is the legal regulation of this area by the government. In many foreign countries a number of conceptual, doctrinal and program documents are adopted and implemented, which are dealing with the use of renewable energy sources. In order to stimulate the use of alternative energy sources, the governments of some countries create favorable conditions for attracting investment in the development of this sector, which, further, not only creates new jobs, but also has a generally positive effect on the economy.
\end{abstract}

\section{Introduction}

The world energy system has long been standing on the verge of energy shortage problems. The rapid depletion of natural raw materials, as well as the detrimental impact on the environment bring the task of more active use of alternative energy sources to the foreground, which in the near future will inevitably lead to reducing the role of oil, natural gas and coal.

For example, the power sector is the major source of air pollution and greenhouse gas emissions in China due to its intensive coal combustion. Facing pressing local health penalties and global climate change pressures, China has taken actions to reduce its power sector's reliance on coal, by either transforming its energy portfolio or improving coal-burning efficiencies [14].

The main advantage of alternative sources is their renewability, environmental friendliness, inexhaustibility and availability when using modern technologies to obtain them. The main factor that stimulates the development of this power industry in the world is the need to reduce environmental pollution.

Many world countries actively use non-traditional types of energy for a long time. Unfortunately Russia is only at the stage of developing this industry. Possessing significant potential for the use of alternative energy sources, Russia didn't use them for power needs until the 2000s, although developments in this area have been going on since the 1950s and 1960s. The main world prerequisites for a steadily growing share of alternative energy are the desire to reduce the country's dependence on hydrocarbon imports, which is primarily associated with political risks; the solution of environmental problems associated with emissions of carbon dioxide into the atmosphere; reducing the cost of the generated energy.

\section{Literature review}

Many scientists studied the issues of tax incentives for the use of alternative energy sources. The authors fully share the view that the use of tax instruments gives good results in expanding the development, production and use of equipment generating energy from renewable sources (Walid Oueslati, Vera Zipperer, Damien Rousselière, Alexandros Dimitropoulos, 2017) [4] and (Xiaoli Zhao, Jin Yao, Chuyu Sun, Wengeng Pan, 2018) [5].

Research work (Stephen Comello, Stefan Reichelstein, David D.J. Taylor, Santiago Paiva, Alexander H. Slocum, 2017) [7] confirmed the efficiency of investment tax credits, which allowed a significant increase in the amount of energy generated by solar panels in the USA. Others authors (Robert Godby, David T. Taylor, Roger Coupal, 2018) [6] write about new opportunities for rural communities in the USA in the use of wind energy, which gives the state tax policy. There is a direct correlation between the increase in carbon tax and the increase in household use of solar panels (Ahmad F. Ghaith, Francis M. Epplin, 2017) [8]. A similar relationship has been revealed between environmental taxes and enterprises' investments in new energy generation technologies (Tsai Chi Kuo, I-Hsuan Hong, Sheng Chun Lin, 2016) [9]. Other researchers came to the same conclusions (Wen-Hsien Tsai, Shi-Yin Jhong, 2019) [10]. A number of studies have been carried out on taxation practices in individual territories: including taxation of mining (Kyle A. Hoy, Douglas H.

Corresponding author: ilyashenko.sb@ rea.ru 
Wrenn, 2018) [12]. During investigation the efficiency of environmental taxes, David DJ Taylor, Santiago Paiva, Alexander H. Slocum (2017) [11] and Robert K. Kaufmann (2019) [13] concluded that as an alternative it is expedient to enable enterprises to reinvest profits in alternative energy sources.

\section{Materials and methods}

During this study, general scientific research methods were used, such as observation, analysis and synthesis, induction and deduction, comparison and description, qualitative and quantitative analysis. For the data collection and processing we used such methods as grouping, generalization, classification, systematization and modeling.

During the processing of information concerning the interest of consumers in developing state support measures when deciding on the possibility of using alternative energy sources in practice, we determined criteria that determine the feasibility of using tax instruments that encourage the use of alternative energy sources.

We have stated the following hypothesis: the provision of benefits from the state will be aimed at creating interest and increasing the activity of various groups of taxpayers in the use of alternative energy sources.

\section{Results}

In Russia, the share of alternative energy sources in 2016 was a little over $17 \%$ of the total generated energy (Table 1). This value is mainly obtained due to industrial hydropower plants.

The Russian indicator of the share of electrical energy generated from alternative sources (Table 1) is comparable to that of the European Union (Table 2). However, by contrast with the Russian Federation, for the European Union not only hydropower, but also wind and solar energy are important sources. There, in 2016, water energy gave $7.4 \%$, sun energy $-3.2 \%$, and wind energy $-6.4 \%$ of $17 \%$ of the electricity produced by an alternative way. Whereas for the same period in Russia, hydropower accounted for $16.9 \%$ of the $17 \%$ of electricity generated from renewable sources.

According to the System Operator of the Unified Energy System (SO UES) of the Russian Federation, the total installed electrical capacity of solar power plants of UES of Russia was only $0.34 \%$ of the installed capacity of the power plants of the power system, and the total installed electrical capacity of wind power plants was $0.08 \%$ [15] as of January 1, 2019.

According to the SO UES, there are 35 solar power plants in Russia, of which 7 are located in the Orenburg Oblast, 6 in the Republic of Crimea, 5 in the Astrakhan Oblast, 5 in the Altai Republic, 3 in the Saratov Oblast, 3 in the Republic of Bashkortostan and one each in the Belogorod, Volgograd, Samara Oblast, the Republic of Buryatia, the Republic of Khakassia and the Khabarovsk

Table 1. Electrical energy production in the Russian Federation* [13].

\begin{tabular}{|c|c|c|c|c|c|c|c|}
\hline & 2010 & 2011 & 2012 & 2013 & 2014 & 2015 & 2016 \\
\hline $\begin{array}{l}\text { Produced electrical } \\
\text { energy, mln. kWh }\end{array}$ & 1038032.7 & 1054857.5 & 1069289.3 & 1059085.5 & 1064196.5 & 1067543.3 & 090970.2 \\
\hline \multicolumn{8}{|l|}{$\begin{array}{c}\text { Including that generated } \\
\text { by power plants : }\end{array}$} \\
\hline - Heat & 698716.4 & 716569.5 & 726407.3 & 703474.8 & 707462.3 & 701218.9 & 706660.6 \\
\hline - Nuclear & 170414.7 & 172941.3 & 177533.9 & 172508.1 & 180757.4 & 195470.2 & 196614.4 \\
\hline -Hydropower & 168397.5 & 164819.6 & 164875.7 & 182654.6 & 175268.5 & 169914.2 & 186639.5 \\
\hline - Non-typical & 504.8 & 527.4 & 462.9 & 449.0 & 719.1 & 939.9 & 1055.7 \\
\hline $\begin{array}{l}\text { The share of electrical } \\
\text { energy produced from } \\
\text { alternative sources, \% }\end{array}$ & 16.3 & 15.7 & 15.5 & 17.3 & 16.5 & 16 & 17 \\
\hline
\end{tabular}


Table 2. Electrical energy consumption in the European Union * [14].

\begin{tabular}{|l|c|c|c|c|c|c|c|}
\hline & $\mathbf{2 0 1 0}$ & $\mathbf{2 0 1 1}$ & $\mathbf{2 0 1 2}$ & $\mathbf{2 0 1 3}$ & $\mathbf{2 0 1 4}$ & $\mathbf{2 0 1 5}$ & $\mathbf{2 0 1 6}$ \\
\hline $\begin{array}{l}\text { Electrical energy, produced } \\
\text { from all sources, TJ }\end{array}$ & 042197 & 833537 & 926465 & 989542 & 101643 & 106390 & 104245 \\
0 & 0 & 0 & 0 & 80 & 30 & 40 \\
& & & & & & & \\
\hline $\begin{array}{l}\text { Electrical energy, produced } \\
\text { from renewable sources, TJ }\end{array}$ & $\begin{array}{c}733553 \\
5.7\end{array}$ & $\begin{array}{c}723509 \\
8.9\end{array}$ & $\begin{array}{c}793053 \\
4.7\end{array}$ & $\begin{array}{c}839131 \\
5.4\end{array}$ & $\begin{array}{c}852791 \\
2.3\end{array}$ & $\begin{array}{c}886230 \\
9.3\end{array}$ & $\begin{array}{c}906934 \\
9.8\end{array}$ \\
\hline $\begin{array}{l}\text { The share of electrical } \\
\text { energy, produced from } \\
\text { renewable sources, \% }\end{array}$ & 12.9 & 13.2 & 14.4 & 15.2 & 16.1 & 16.7 & 17 \\
\hline \begin{tabular}{l} 
*According to the Eurostat data http://ec.europa.eu/eurostat/web/energy/data/database \\
\hline
\end{tabular}
\end{tabular}

Krai, respectively.

The following measures are the most widespread in many countries, which are enshrined in legal acts: special tariffs for the purchase of "green energy", financed from the state budget, subsidies for renewable energy producers, "green certificates", soft loans, remission from payment environmental taxes, etc. For example, in Japan, the state undertakes a commitment to refund the costs of the purchase and even, in some cases, the maintenance of equipment necessary for the production of "green energy". The rate of income tax and VAT are also reduced, "harmful emissions" taxes are introduced, encouraging owners to switch to the use of environmentally friendly equipment.

\section{Discussion}

Nowadays, the development of alternative energy sources, primarily solar and wind, usage in decentralized power supply systems is particularly relevant for Russia. Low population density and poor development of transport, energy, production infrastructure in most parts of the country, obviously, determine the relevance and competitiveness of renewable energy sources in such zones.

In countries where alternative energy sources are widespread, other infrastructure conditions are created: geographically compact networks, state refunding of expenses for the fields of wind power stations; there exists a return of energy to the city network if it is not fed by batteries.

Of course, the development of alternative energy in Russia is partially driven by the absence of a tax on the use of wind generators and solar batteries by individuals. However, the constraining factor is the lack of financial opportunities for individuals to purchase and install equipment. Here the possibility of applying a tax deduction on the tax on personal income for citizens to purchase wind generators, solar panels and other devices that generate electricity from renewable sources could become a tax incentive. This tax benefit is a tax exemption for an individual's income in the amount spent on the acquisition of equipment for the generation of alternative energy.

\section{Conclusions}

Nowadays it can be said that alternative energy has a great success. This is noted by the fact that more and more companies and investors are responding to the increasing role of alternative energy sources in meeting energy demand. Today there is a steady increase in the number of mergers and acquisitions in the field of wind and solar energy. By the volume of attracted investments in alternative energy sources, wind energy sector became the second largest after the solar (103 billion rubles and 191 billion rubles, respectively) for 2013-2016.

However, for the full development of alternative energy and improving the energy efficiency of sectors of the national economy, it is necessary to consider the possibility of introducing tax incentives for enterprises, as well as expanding the list of measures subject to income tax compensation for individuals. This would allow more consumers of utility resources to be interested in the use of alternative energy sources within their activities.

\section{References}

1. Electricity consumption in the European Union. Eurostat. [Electronic resource]. https://ec.europa.eu/eurostat/web/energy/data/datab ase

2. The share of electricity from alternative sources in the European Union countries. Eurostat. [Electronic resource].

http://appsso.eurostat.ec.europa.eu/nui/show.do?dat aset $=$ nrg ind $335 \mathrm{a} \&$ lang $=$ en

3. Production and distribution of electricity. Federal State Statistics Service of the Russian Federation. [Electronic resource] http://www.gks.ru/free_doc/new_site/business/pro $\mathrm{m} /$ natura/mes $10 . h$ tm 
4. W. Oueslati, V. Zipperer, D. Rousselière, A. Dimitropoulos, Energy taxes, reforms and income inequality: An empirical cross-country analysis, International Economics, 150, 80-95 (2017) ISSN 2110-7017, https://doi.org/10.1016/j.inteco.2017.01.002.

5. X. Zhao, J. Yao, Ch. Sun, W. Pan, Impacts of Carbon Tax and Tradable Permits on Wind Power Investment in China, Renewable Energy (2018) ISSN 0960-1481, https://doi.org/10.1016/j.renene.2018.09.068.

6. R. Godby, D.T. Taylor, R. Coupal, Wind development, tax policy and economic development tradeoffs, The Electricity Journal, 31(5), 46-54 (2018) ISSN 1040-6190, https://doi.org/10.1016/j.tej.2018.06.001.

7. S. Comello, S. Reichelstein, D.J. Taylor, S. Paiva, A.H. Slocum, An alternative to carbon taxes to finance renewable energy systems and offset hydrocarbon based greenhouse gas emissions, Sustainable Energy Technologies and Assessments, 19, 136-145 (2017) ISSN 2213-1388, https://doi.org/10.1016/j.seta.2017.01.003.

8. A.F. Ghaith, F.M. Epplin, Consequences of a carbon tax on household electricity use and cost, carbon emissions, and economics of household solar and wind, Energy Economics, 67, 159-168 (2017) ISSN 0140-9883, https://doi.org/10.1016/j.eneco.2017.08.012.

9. T.Ch. Kuo, I.H. Hong, S.Ch. Lin, Do carbon taxes work? Analysis of government policies and enterprise strategies in equilibrium, Journal of Cleaner Production, 139, 337-346 (2016) ISSN 0959-6526, https://doi.org/10.1016/j.jclepro.2016.07.164.

10. W.H. Tsai, Sh.Y. Jhong, Production decision model with carbon tax for the knitted footwear industry under activity-based costing, Journal of Cleaner Production, 207, 1150-1162 (2019) ISSN 09596526, https://doi.org/10.1016/j.jclepro.2018.09.104.

11. D.J. Taylor, S. Paiva, A.H. Slocum, An alternative to carbon taxes to finance renewable energy systems and offset hydrocarbon based greenhouse gas emissions, Sustainable Energy Technologies and Assessments, 19, 136-145 (2017) ISSN 22131388, https://doi.org/10.1016/j.seta.2017.01.003.

12. K.A. Hoy, D.H. Wrenn, Unconventional energy, taxation, and interstate welfare: An analysis of Pennsylvania's severance tax policy, Energy Economics, 73, 53-65 (2018), ISSN 0140-9883, https://doi.org/10.1016/j.eneco.2018.05.002.

13. R.K. Kaufmann, Pass-through of motor gasoline taxes: Efficiency and efficacy of environmental taxes, Energy Policy, 125, 207-215 (2019) ISSN 0301-4215, https://doi.org/10.1016/j.enpol.2018.10.045.

14. X. Liao, J.W. Hall, Drivers of water use in China's electric power sector from 2000 to 2015 , Environ. Res. Lett., 13 (2018). https://doi.org/10.1088/17489326/aada3a

15. The structure of the installed capacity of power plants of the Unified Energy System of Russia.
[Electronic resource]. http://www.soUES.ru/index.php?id=ees 